\title{
Article \\ Quantification of Submarine Groundwater Discharge in the Gaza Strip
}

\author{
Ashraf M. Mushtaha ${ }^{1,2, *(D)}$ and Kristine Walraevens ${ }^{2}$ (D) \\ 1 Environmental Affairs and MIS Departments, Gaza Strip, Palestine \\ 2 Laboratory for Applied Geology and Hydrogeology, Ghent University, Krijgslaan 281-S8, \\ 9000 Gent, Belgium; kristine.walraevens@ugent.be \\ * Correspondence: amushtaha@gmail.com
}

Received: 29 September 2018; Accepted: 7 December 2018; Published: 10 December 2018

\begin{abstract}
Gaza Strip has suffered from seawater intrusion during the past three decades due to low rainfall and high abstraction from the groundwater resource. On a yearly basis, more than 170 million $\mathrm{m}^{3}$ of groundwater is abstracted, while the long-term average recharge from rainfall is 24.4 million $\mathrm{m}^{3}$ /year. Submarine groundwater discharge (SGD) has never been studied in the Gaza Strip, due to lack of experience in this field, next to the ignorance of this subject due to the seawater intrusion process taking place. Continuous radon measurements were carried out in six sites along the Gaza Strip to quantify the SGD rate. The final result shows SGD to occur in all sampled sites. The range of SGD rates varies from 0.9 to $5.9 \mathrm{~cm} \cdot \mathrm{day}^{-1}$. High values of SGD are found in the south (Rafah and Khan Younis governorates). The high values are probably related to the shallow unconfined aquifer, while the lowest values of SGD are found in the middle of Gaza Strip, and they are probably related to the Sabkha formation. In the north of Gaza Strip, SGD values are in the range of 1.0 to $2.0 \mathrm{~cm} \cdot$ day $^{-1}$. Considering that SGD would occur with the measured rates in a strip of $100 \mathrm{~m}$ wide along the whole coast line, the results in a quantity of 38 million $\mathrm{m}^{3}$ of groundwater being discharged yearly to the Mediterranean Sea along Gaza coast. Nutrient samples were taken along Gaza Strip coastline, and they were compared to the onshore wells, $600 \mathrm{~m}$ away from the Mediterranean Sea. The results show that SGD has higher $\mathrm{NO}_{3}{ }^{-}+\mathrm{NO}_{2}{ }^{-}$than nutrient-poor seawater, and that it is close to the onshore results from the wells. This confirms that the source of SGD is groundwater, and not shallow seawater circulation. In a coastal strip of $100 \mathrm{~m}$ wide along the Gaza coast, a yearly discharge of over 400 tons of nitrate and 250 tons of ammonium occurs from groundwater to the Mediterranean Sea.
\end{abstract}

Keywords: SGD; SGD model; Radon; coastal aquifer; nutrient discharge; Gaza Strip

\section{Introduction}

Although Submarine groundwater discharge (SGD) may not play a significant role in the global water balance, there are reasons to believe that the geochemical cycles of some major and minor elements may be strongly influenced either by the direct discharge of fresh groundwater into the sea, or by chemical reactions that occur during the recirculation of seawater through a coastal aquifer system [1-3]. Groundwater contamination, being a wide-spread problem, SGD may bring pollution to coastal seawater [3,4]. SGD affects the nutrient balance of the sea near the coast, causing harmful algal blooms and changing the flora and fauna of coastal waters [5-10].

Several papers have emphasized the important role of recirculated seawater in the transport of solutes from aquifers to coastal water. Moore [2] proposed the term "subterranean estuary (STE)" for the aquifer zone, where recirculating seawater mixes with fresh groundwater, and where water-rock interaction affects the mobility of constituents, including nutrients, towards the sea [11]. Lebbe [12], 
as well as Werner and Lockington [13], have demonstrated that tidal fluctuations can induce saltwater recirculation in the upper aquifer, producing a saline water table in the coastal fringe.

Measuring SGD by traditional hydrogeological or water balance estimates may be off by several orders of magnitude, largely because of difficulties in constraining hydraulic conductivities. Yet, quantifying SGD is important, as concentrations of dissolved constituents in SGD are often greater than in surface waters, resulting in significant groundwater-derived solute contributions $[10,14]$. One potential means of evaluating groundwater pathways and fluxes into the coastal zone more accurately is through the use of natural tracers, where ${ }^{222} \mathrm{Rn}$ is an excellent tracer [3,15-18]. The very large enrichment of ${ }^{222} \mathrm{Rn}$ concentration in groundwaters over surface waters (usually 1000-fold or greater), and its unreactive nature and short half-life $\left(\mathrm{t}_{1 / 2}=3.83\right.$ days) make ${ }^{222} \mathrm{Rn}$ an excellent tracer to identify areas of significant groundwater discharge [3,19]. Continuous radon monitoring (RAD 7-device with RAD-AQUA) could provide reasonably high-resolution data on the radon concentration of coastal seawater at one location over time [20].

In the past three decades, researchers were focusing on the seawater intrusion phenomenon in Gaza Strip, while no one has tackled the reverse flow direction, to establish whether it may occur in the hydrogeological setting. This study focuses on the submarine groundwater discharge from different places along the Gaza coastline using continuous radon measurements with RAD7 and RAD-AQUA devices, beside nutrient analysis along the shoreline and onshore in monitoring wells.

\section{Hydrogeological Background}

Gaza Strip is a coastal area along the eastern Mediterranean Sea and lies at latitude $31^{\circ} 25^{\prime} 59^{\prime \prime} \mathrm{N}$ and longitude $34^{\circ} 22^{\prime} 34^{\prime \prime}$ E. Gaza Strip forms a transition zone between the semi-humid coastal zone in the north, the semi-arid zone in the east, and the Sinai desert in the south. Gaza Strip has a surface area of $365 \mathrm{~km}^{2}$ where more than 1.8 million inhabitants are living. Groundwater is the only water source for the population of Gaza [21].

The Kurkar Group stratigraphy of Gaza Strip near the coast subdivides the aquifer into four sub aquifers (sub-aquifers A, B1, B2 and C), separated by marine clay layers, whereas in the east, there is only one aquifer (Figure 1). Those sub-aquifers are semi-confined near the coast, except for the upper layer. The bottom of the aquifer is an impermeable layer known as the Saqiya Group (Miocene-Pliocene age), which is a very thick sequence of marls, marine shales, and clay stones [22]. The Saqiya Group pinches out at around $10 \mathrm{~km}$ to $15 \mathrm{~km}$ from the coast in the South of Gaza Strip, and the coastal aquifer rests directly on Eocene-age chalk. The saturated thickness of the Gaza coastal aquifer near the coast is around $180 \mathrm{~m}$ in the North West, while it is around $40 \mathrm{~m}$ at the North Eastern border, and in the South East, it is only few meters ( $5 \mathrm{~m}$ to $10 \mathrm{~m}$; [23]). The Gaza Strip has more than 5000 wells distributed all over the area; 200 wells are used for the water supply system, and the rest are either agricultural or private wells [24].

As a result of aquifer exploitation and imbalance between recharge and abstraction in the past few decades, the groundwater level has dropped to more than $10 \mathrm{~m}$ below mean sea level in the southern part of Gaza Strip $[21,24]$. The yearly groundwater decline rate varies from north to south: in the north, it ranges between 10 to $30 \mathrm{~cm}$, and in the south, it reaches $70 \mathrm{~cm}$ [25]. 


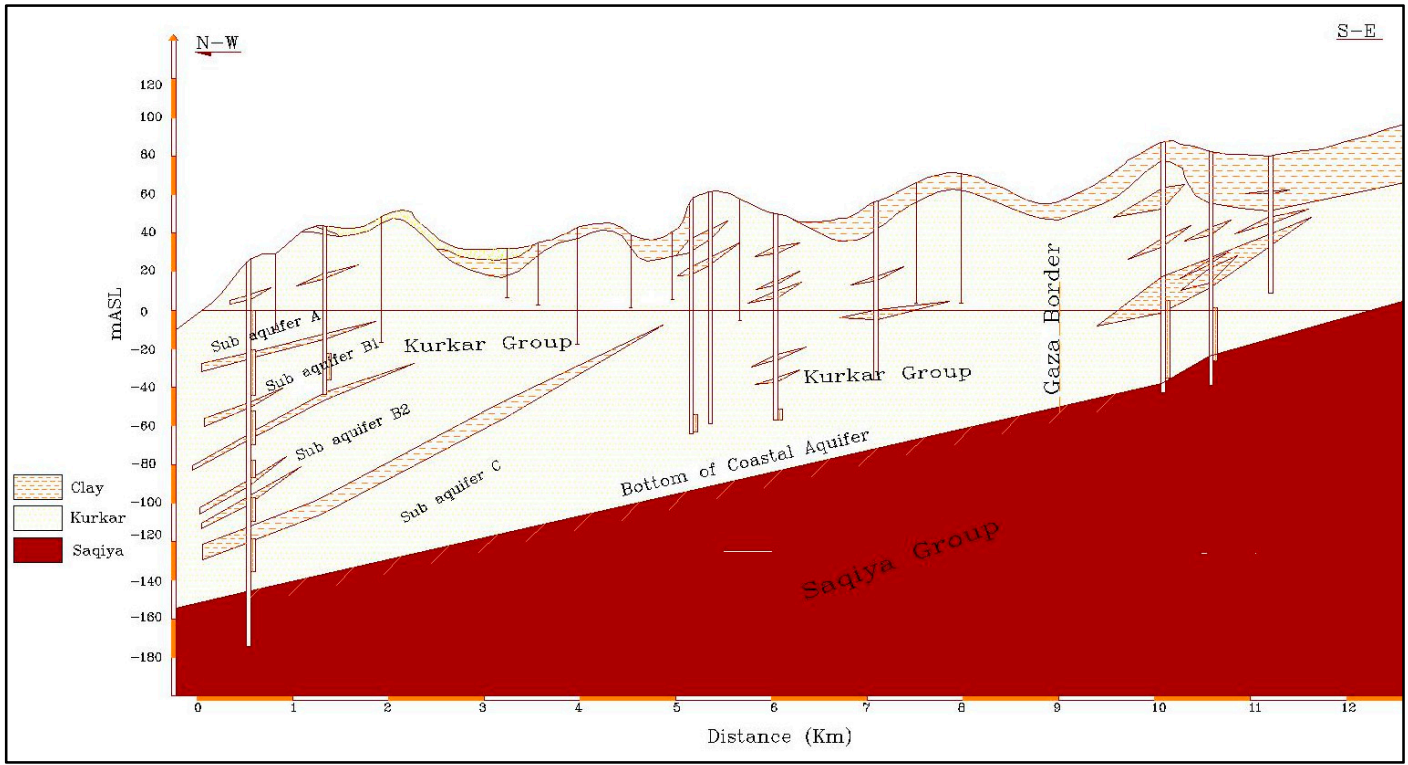

Figure 1. Typical cross-section of the Gaza Aquifer (after [26]).

\section{Materials and Methods}

\subsection{Measurement of Nutrients in Groundwater}

Coastal aquifers facilitate the interaction of nutrient-rich groundwater with nutrient-poor seawater. This is especially important in oligotrophic settings, such as the eastern Mediterranean, where the $\left(\mathrm{NO}_{3}{ }^{-}+\mathrm{NO}_{2}{ }^{-}\right)$content of seawater is typically $<100 \mu \mathrm{M}[11,27]$. Nutrient sampling of shallow groundwater was done to find indications of SGD, in order to select the best locations for radon measurements. A total of 232 water samples have been collected, 228 of them are groundwater samples taken along the Gaza coastline (51 samples in the north, 68 in the middle and 109 in the south), with a distance ranging from 10 to $20 \mathrm{~m}$ from the high-tide line, after digging for 1 to $1.2 \mathrm{~m}$ in the beach sand. Four samples were collected from shallow groundwater wells within $600 \mathrm{~m}$ from the coastline, which penetrate a few meters in the groundwater (in the south of the Gaza Strip). All collected samples were analyzed for nitrate $\left(\mathrm{NO}_{3}{ }^{-}\right)$, nitrite $\left(\mathrm{NO}_{2}{ }^{-}\right)$, ammonia $\left(\mathrm{NH}_{4}{ }^{+}\right)$, phosphate $\left(\mathrm{PO}_{4}{ }^{3-}\right)$, and salinity. Figure 2A shows the coastal samples' location (232 groundwater samples) and the grouping based on the sample location. Each group of coastal samples were averaged based on location: north, middle, and south of the Gaza Strip.

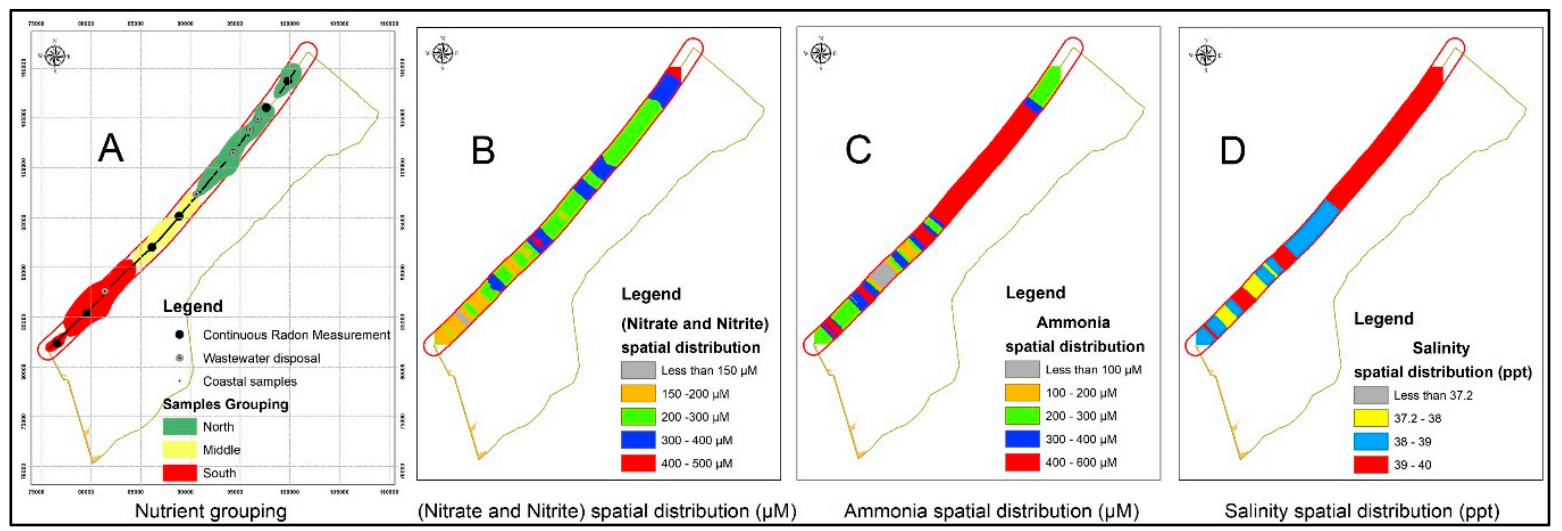

Figure 2. Nutrient sampling location and grouping, spatial distribution for $\mathrm{NO}_{3}{ }^{-}+\mathrm{NO}_{2}{ }^{-}, \mathrm{NH}_{4}{ }^{+}$, and salinity (map grid according to the Palestinian Grid System 1923). (A) Samples grouping vs wastewater disposal location; (B) Spatial distribution of $\mathrm{NO}_{3}{ }^{-}+\mathrm{NO}_{2}{ }^{-}$along the coastline; (C) Spatial distribution of $\mathrm{NH}_{4}{ }^{+}$along the coastline; (D) Spatial distribution of salinity along the coastline. 
Samples locations were verified, to make sure that sewage outflow to the sea was avoided. Six locations were selected based on high nutrient concentrations to demonstrate SGD using RAD7 with RAD-AQUA for the continuous measurement of radon. Three maps of $\mathrm{NO}_{3}{ }^{-}+\mathrm{NO}_{2}{ }^{-}, \mathrm{NH}_{4}{ }^{+}$, and salinity were included to show the selection of the SGD locations (see Figure 2B-D).

\subsection{Measurement of Radon Concentrations in Groundwater}

Groundwater is enriched in radon compared to the surface water. While most of the radon $\left({ }^{222} \mathrm{Rn}\right)$ pore water is produced from particle-surface-bound radium $\left({ }^{226} \mathrm{Ra}\right)$, and the accumulation of the radium is likely regulated by the presence of manganese (hydr)oxides [28].

Radon has greater utility than radium as a SGD tracer when the discharge is fresh or a mixture of fresh and recirculated seawater, since any groundwater in the aquifer (independent of its salinity) is enriched in radon, due to its contact with the sediments and rocks. Radon-enriched fluid is transported to coastal waters, and a radon mass balance can be used to calculate total submarine groundwater discharge [28]. The main sources of uncertainty in the radon mass balance model are associated with:

(1) quantifying ${ }^{222} \mathrm{Rn}$ loss by evasion to the atmosphere [29],

(2) quantifying ${ }^{222} \mathrm{Rn}$ loss via mixing with offshore waters [30] and

(3) characterizing the groundwater end-member radon activity that supplied the measured excess $\mathrm{Rn}$ in coastal waters [31-33].

Since radon is an inert gas, we may expect that the sediment and/or rock uranium/radium content is the main source of radon; it is not produced by chemical reactions or pore water chemistry [28]. The sole source of radon $\left({ }^{222} \mathrm{Rn}\right.$ with a half time of 3.8 days) in groundwater is the radioactive decay of radium $\left({ }^{226} \mathrm{Ra}\right.$ with a half time of 1600 years). Radium, the parent of radon, can be retained on grain surface coatings, bound in the mineral lattice of the aquifer matrix, and dissolved in pore water [2]. The short half-life of ${ }^{222} \mathrm{Rn}$ makes it an excellent tracer to identify areas of significant groundwater discharge [34].

The automated radon system analyses ${ }^{222} \mathrm{Rn}$ from a constant stream of water produced by a submersible pump and passed through an air-water exchanger, which distributes radon from the running flow of water to a closed air loop. The air stream is fed to the radon-in-air monitor. The radon concentration in the water can easily be calculated from the known temperature dependence of the radon distribution at equilibrium between the air and water phases [20].

Measurements of radon concentrations in the water column have been accomplished by standard oceanographic sampling and analysis techniques (radon emanation) for measurement of ${ }^{222} \mathrm{Rn}$ taking the special care required for trace gas sampling [3,35,36]. Recently, "continuous" radon monitoring has been described, which can provide high-resolution data on the radon concentration of coastal seawater at one location over time $[3,20]$.

The operation principle of the RAD AQUA device is the closed air loop in which the radon concentration reaches equilibrium during water supply flow. The radon concentration in the water compared to radon concentration in the air is governed by a temperature coefficient of 0.25 at room temperature [3], meaning that four times more radon is present in the air, compared to water. This has a favorable impact on measuring accuracy.

Six locations along the Gaza Strip coastline were measured for continuous radon, to assess the SGD (Figure 3): two locations in the north, two in the middle, and two in the south of the Gaza Strip. 


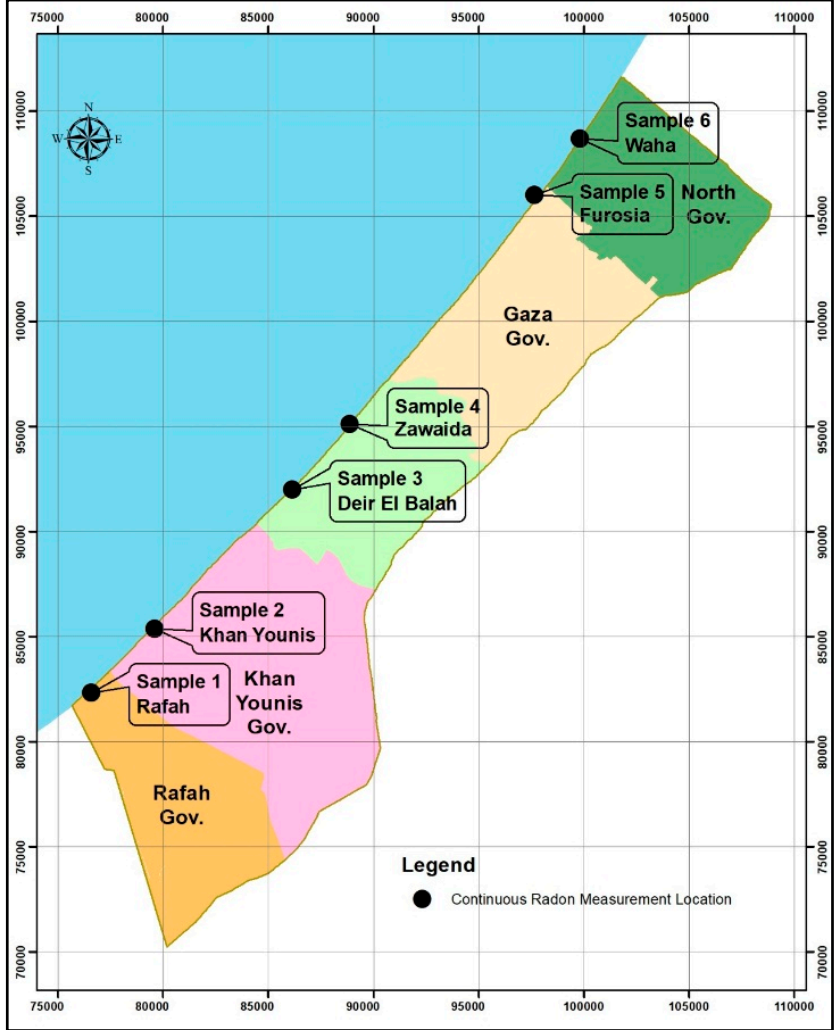

Figure 3. Continuous radon measurement location.

\subsection{Field Work}

To measure the submarine groundwater discharge using radon as a groundwater tracer, RAD7 and RAD-AQUA were used together to measure continuous radon in water in six locations in the Gaza Strip (Figure 3). A submersible pump was placed at the sea floor (at a depth ranging from 0.83 to $1.05 \mathrm{~m}$ ), pumping water from the seafloor through a hose to the RAD-AQUA device for spraying, while the RAD7 measures the produced radon from the sprayed water. We initially intended to measure temporal changes of SGD, but due to the situation in the Gaza Strip, we were unable to do this. The time duration for sampling was different in each sampling location according to the field situation and obstacles found in the field. The duration ranged from $1.5 \mathrm{~h}$ to 2 days. In the middle part of Gaza Strip (Deir El Balah governorate), two short measurements were carried out, ranging from 1.5 to $3 \mathrm{~h}$; due to some practical constraints, we were not able to spend more time for measuring at these sites. Table 1 shows the location and duration of each measurement.

Table 1. General information about the continuous radon measurement locations.

\begin{tabular}{|c|c|c|c|c|c|}
\hline \multirow{2}{*}{ Area } & \multirow{2}{*}{ Site Name } & \multicolumn{2}{|c|}{$\begin{array}{c}\text { Coordinates } \\
\text { (Palestinian Grid System 1923) }\end{array}$} & \multirow{2}{*}{$\begin{array}{l}\text { Continuous Radon Measurement } \\
\text { Time Duration (Hours:Minutes) }\end{array}$} & \multirow{2}{*}{ Date of Measurement } \\
\hline & & $x$ & Y & & \\
\hline \multirow{2}{*}{ South } & Rafah & $76,581.88$ & $82,326.76$ & $7: 15$ & 12 February 2014 \\
\hline & Khan Younis & $79,585.25$ & $85,385.75$ & $12: 30$ & 11-12 February 2014 \\
\hline \multirow{2}{*}{ Middle } & Deir El Balah & $86,148.19$ & $92,004.30$ & 3:00 & 19 February 2014 \\
\hline & Zawaida & $88,873.47$ & $95,118.91$ & $1: 30$ & 19 February 2014 \\
\hline \multirow{3}{*}{ North } & Furosia & $97,661.13$ & $106,020.06$ & $47: 30$ & 2-4 March 2014 \\
\hline & Waha & 9983023 & 10868972 & $9: 30$ & 1 March 2014 \\
\hline & (two tests) & & & $11: 30$ & 2 March 2014 \\
\hline
\end{tabular}

\subsection{SGD Model from Radon Tracing}

Estimating groundwater discharge via radon is based on a mass balance approach. Inventories are measured, either as a snapshot or continuously over time, and these inventories are converted to input 
fluxes after making allowances for losses, due to decay, atmospheric evasion, and net coastal "mixing" terms. Although changing radon concentrations in coastal waters could be in response to a number of processes, the advective transport of radon-rich groundwater (pore water) through sediment is often the dominant process [37]. Thus, if one can measure or estimate the radon concentration in these advecting fluids, the ${ }^{222} \mathrm{Rn}$ fluxes may be easily converted to water fluxes. ${ }^{222} \mathrm{Rn}$ is also produced by ${ }^{226} \mathrm{Rn}$ in the sampled water, and this quantity has to be subtracted to obtain "Excess ${ }^{222} \mathrm{Rn}$ ", which is relevant for our purposes. The inventory refers to the total amount of excess ${ }^{222} \mathrm{Rn}\left({ }^{222} \mathrm{Rn}\right.$ in water minus ${ }^{226} \mathrm{Rn}$ in pore water) per unit area. Decay is not considered because the fluxes are evaluated on a very short (1-2 h) time scales that are relative to the half-life of ${ }^{222} \mathrm{Rn}$ [38].

The following data are required to perform the analysis: continuous measurement of total ${ }^{222} \mathrm{Rn}$ activities $\left(\mathrm{dpm} \cdot \mathrm{m}^{-3}\right)$ in the coastal water column, water depth measurement, water and air temperatures, wind speed, atmospheric ${ }^{222} \mathrm{Rn}$ concentrations, and ${ }^{226} \mathrm{Ra}$ in the coastal water.

RAD7 device measures the total ${ }^{222} \mathrm{Rn}\left(\mathrm{dpm} \cdot \mathrm{m}^{-2}\right)$ in the water column every $30 \mathrm{~min} .{ }^{226} \mathrm{Ra}$ could not be measured during our research; hence, it has been taken from Weinstein et al. [39]. They measured ${ }^{226}$ Ra several times (Carmel coast in Israel, $60 \mathrm{~km}$ to the north of Gaza Strip) by gamma spectrometry, to show ${ }^{226} \mathrm{Ra}$ activity in the range of $200-240 \mathrm{dpm} / \mathrm{kg}$ in the sand. On the other hand, they found ${ }^{222} \mathrm{Rn}$ in pore water to be in a range of 340 to $390 \mathrm{dpm} \cdot \mathrm{L}^{-1}$ for the Kurkar groundwater [39].

Due to un-accessibility to measure the ${ }^{222} \mathrm{Rn}$ activity offshore, we used the value of $1000 \mathrm{dpm} \cdot \mathrm{m}^{-3}$ taken from Peterson et al. [40]. The wind speed at the time of measurement was taken from http:/ / www.wunderground.com.

We used the various assumptions that are inherent in the application of a ${ }^{222} \mathrm{Rn}$ box model as stated in Burnett and Dulaiova [3], Dulaiova et al. [30] and Burnett et al. [38], to derive a rate of submarine groundwater discharge.

\section{Results}

\subsection{Nutrients}

High contents of $\left(\mathrm{NO}_{3}{ }^{-}+\mathrm{NO}_{2}{ }^{-}\right)$in the coastal samples may be representing SGD (Figure 4A). The average groundwater concentration is $440 \mu \mathrm{M}$ in wells, while in the coastal samples, the concentration ranges from 204.6 to $320.1 \mu \mathrm{M}$. A trend of decreasing $\left(\mathrm{NO}_{3}{ }^{-}+\mathrm{NO}_{2}{ }^{-}\right)$(Table 2$)$ is shown from the north to the south of Gaza Strip. Literature states that fresh groundwater concentration for $\left(\mathrm{NO}_{3}{ }^{-}+\mathrm{NO}_{2}{ }^{-}\right)$is around $330 \mu \mathrm{M}$ [11]. The analyzed concentrations in the coastal samples of our study, thus indeed indicating a substantial contribution of SGD.

The average concentration in the sampled groundwater wells was $4.9 \mu \mathrm{M}$ of $\mathrm{PO}_{4}{ }^{3-}$, while the coastal samples were in the range of 5.6 to $11 \mu \mathrm{M}$ (Table 2 and Figure $4 \mathrm{~B}$ ). Phosphate in the groundwater wells is lower than the measured phosphate in the coastal samples.

Table 2. The number of coastal shallow groundwater nutrient samples and average concentrations in different parts of the Gaza Strip.

\begin{tabular}{|c|c|c|c|c|c|c|c|c|}
\hline Area (Group) & $\begin{array}{l}\text { Number of } \\
\text { Samples }\end{array}$ & $\begin{array}{l}\text { Statistical } \\
\text { Parameter }\end{array}$ & $\begin{array}{l}\mathrm{NO}_{3}^{-} \\
(\mu \mathrm{M})\end{array}$ & $\begin{array}{l}\mathrm{NO}_{2}^{-} \\
(\mu \mathrm{M})\end{array}$ & $\begin{array}{c}\mathrm{NO}_{3}^{-}+ \\
\mathrm{NO}_{2}^{-}(\mu \mathrm{M})\end{array}$ & $\begin{array}{l}\mathrm{NH}_{4}{ }^{+} \\
(\mu \mathrm{M})\end{array}$ & $\begin{array}{c}\mathrm{PO}_{4}{ }^{3-} \\
(\mu \mathrm{M})\end{array}$ & $\underset{\text { (ppt) }}{\text { Salinity }}$ \\
\hline \multirow[b]{2}{*}{ North } & \multirow[b]{2}{*}{51} & Average & 316.2 & 3.9 & 320.1 & 380.8 & 11.0 & 39.6 \\
\hline & & Standard deviation & 167.4 & 4.3 & 167.1 & 152.4 & 7.0 & 0.5 \\
\hline \multirow{2}{*}{ Middle } & \multirow{2}{*}{68} & Average & 254.7 & 9.9 & 264.6 & 373.3 & 6.5 & 38.8 \\
\hline & & Standard deviation & 117.3 & 17.7 & 130.4 & 223.3 & 5.2 & 0.7 \\
\hline \multirow{2}{*}{ South } & \multirow{2}{*}{109} & Average & 201.4 & 3.2 & 204.6 & 362.5 & 5.6 & 38.4 \\
\hline & & Standard deviation & 80.9 & 6.8 & 83.5 & 198.5 & 5.1 & 1.7 \\
\hline \multirow{2}{*}{$\begin{array}{l}\text { Wells } \\
\text { (600 m from the } \\
\text { coastline) }\end{array}$} & \multirow{2}{*}{4} & Average & 424.7 & 15.6 & 440.3 & 360 & 4.9 & 4.9 \\
\hline & & Standard deviation & 262.0 & 30.0 & 276.0 & 201.8 & 6.6 & 4.9 \\
\hline
\end{tabular}



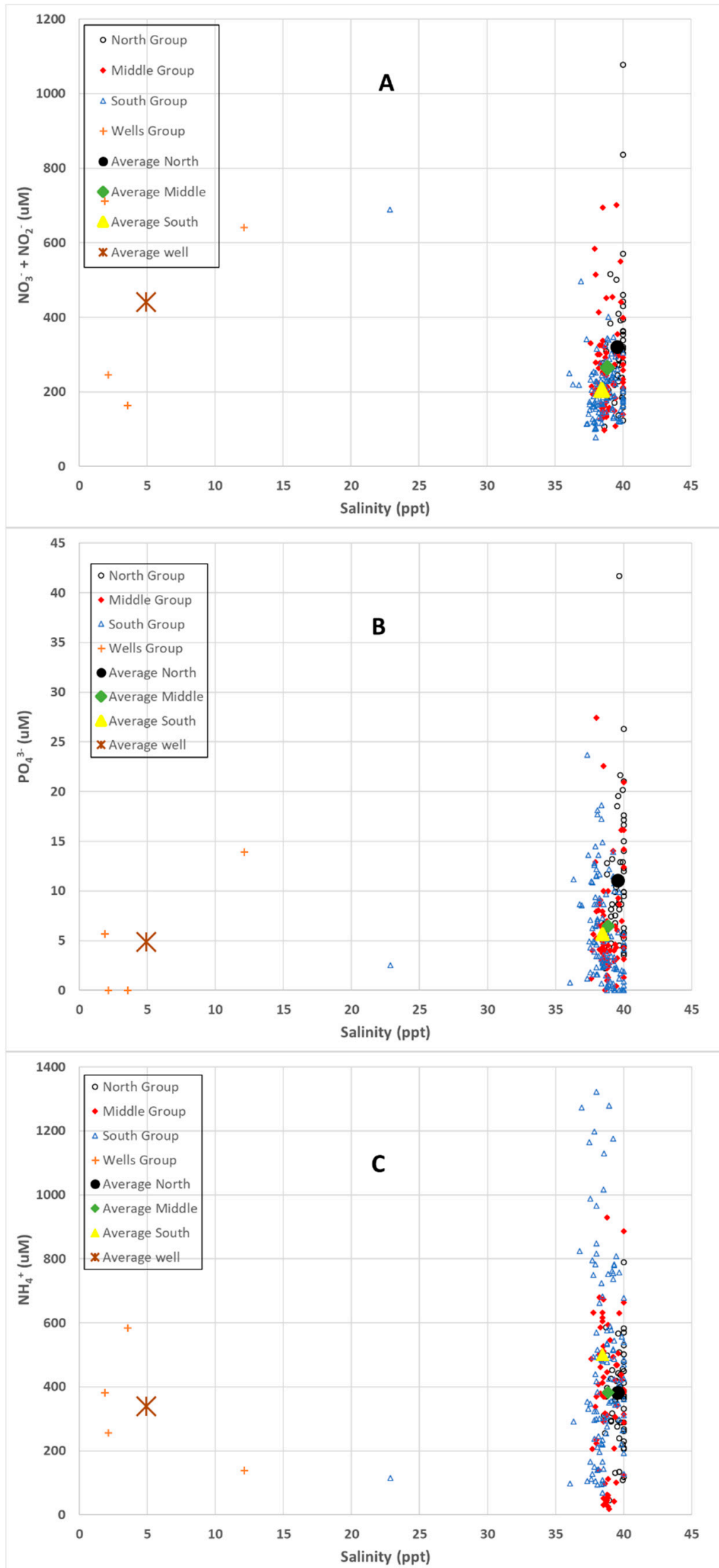

Figure 4. (A) Average $\left(\mathrm{NO}_{3}{ }^{-}+\mathrm{NO}_{2}{ }^{-}\right)$, (B) Average $\mathrm{PO}_{4}{ }^{3-}$ and (C) Average $\mathrm{NH}_{4}{ }^{+}$vs salinity in Gaza coastal shallow groundwater and in deeper wells. 
The average concentration of $\mathrm{NH}_{4}{ }^{+}$in the onshore wells is $360 \mu \mathrm{M}$, while the coastal samples are ranging from 362.5 to $380.8 \mu \mathrm{M}$ (Table 2 and Figure 4C). Hence, the fluxes to the sea have higher $\mathrm{NH}_{4}{ }^{+}$ concentrations than seawater that is poor in $\mathrm{NH}_{4}{ }^{+}$(the ammonia concentrations in seawater vary from $<0.1$ to $15.3 \mu \mathrm{M}[41])$.

The nutrient analytical results for the three groups (north, middle, south) were tested against the significance of their difference, and it was found that, for nitrate, the three groups have significantly different averages at the $5 \%$ significance level. This was not always the case for the other parameters.

\subsection{Radon}

Seven measurements for continuous radon monitoring using RAD7 and RAD-AQUA were carried out in six locations (Figure 3 and Table 1).

The extracted data were processed following the Burnett and Dulaiova [3] model. The results processed by the model are summarized in Table 3, while Figure 5 shows the model results for the SGD flux per unit area based on each sample's time series. Figure 6 illustrates the relationship between the ebb/flood tide (water depth) and the SGD rate at the Furosia location, where positive advection fluxes represent groundwater discharge into the Mediterranean Sea and tend to occur during ebb tide.

In the north, three measurements have been carried out, one in Furosia and two in Waha sites. The Waha site should have one continuous measurement but due to pump failure after $9.5 \mathrm{~h}$, we stopped the measurement and continued with a second measurement after replacing the portable submersible pump. The results show $0.92 \pm 0.27 \mathrm{dpm} \cdot \mathrm{L}^{-1}$ for radon in water at the Furosia site, which results in $1.4 \mathrm{~cm} \cdot$ day $^{-1}$ as an average SGD flux per unit area for two days of measurements. At the Waha site, radon was in the range of $0.37 \pm 0.17$ to $0.45 \pm 0.18 \mathrm{dpm} \cdot \mathrm{L}^{-1}$ and the produced SGD rate is $1.5 \mathrm{~cm} \cdot$ day $^{-1}$ as an average for both measurements. The average SGD rate in the north of Gaza Strip is $1.5 \mathrm{~cm} \cdot$ day $^{-1}$.

In the south of the Gaza Strip, higher radon concentrations were found: $3.51 \pm 0.67$ and $8.2 \pm 1.2 \mathrm{dpm} \cdot \mathrm{L}^{-1}$ in Rafah and Khan Younis, respectively, which produced SGD fluxes per unit area of $5.1 \mathrm{~cm} \cdot$ day $^{-1}$ and $5.9 \mathrm{~cm} \cdot$ day $^{-1}$ in Rafah and Khan Younis, respectively (average of $5.5 \mathrm{~cm} \cdot$ day $^{-1}$ ).

The calculated SGD in the middle part of Gaza Strip showed identical values of $0.9 \mathrm{~cm} \cdot$ day $^{-1}$ at both measuring sites, which gave us some confidence that the produced fluxes, in spite of the short time during which they were measured, were still fine. Further monitoring is recommended to enhance the results.

A sensitivity analysis was carried out to check the effect of the value for ${ }^{222} \mathrm{Rn}$ offshore taken from Peterson et al. [40] (1000 dpm $\left.\cdot \mathrm{m}^{-3}\right)$ to the overall SGD rate calculations, by dividing and multiplying the value for ${ }^{222} \mathrm{Rn}$ offshore by 2 , and re-calculating the SGD rate for each measured location (Table 4). 
Table 3. Results summary of continuous ${ }^{222} \mathrm{Rn}$ measurements.

\begin{tabular}{|c|c|c|c|c|c|c|c|c|c|}
\hline \multirow{2}{*}{ Sample No. } & \multirow{2}{*}{$\begin{array}{c}\text { Area } \\
\text { (Group) }\end{array}$} & \multirow{2}{*}{$\begin{array}{l}\text { LOCATION } \\
\text { NAME }\end{array}$} & \multirow{2}{*}{$\begin{array}{l}\text { No. of } \\
\text { Records }\end{array}$} & \multirow{2}{*}{$\begin{array}{c}\text { Average } \\
\text { Measured }{ }^{222} \mathrm{Rn} \\
\left(\mathrm{dpm} \cdot \mathrm{L}^{-1}\right)\end{array}$} & \multirow{2}{*}{$\begin{array}{l}\text { Average } \\
\text { Depth (m) }\end{array}$} & \multirow{2}{*}{$\begin{array}{c}\text { Average Water } \\
\text { Temperature }\left({ }^{\circ} \mathrm{C}\right)\end{array}$} & \multicolumn{3}{|c|}{ Calculated SGD Rate $\left(\mathrm{cm} \cdot \mathrm{day}^{-1}\right)$} \\
\hline & & & & & & & & & $\begin{array}{c}\text { Standard } \\
\text { Deviation }\end{array}$ \\
\hline \multirow{2}{*}{1} & \multirow{3}{*}{ North } & Waha-1 & 20 & $0.45 \pm 0.18$ & 0.85 & 20.3 & 2.0 & \multirow{3}{*}{1.5} & 1.8 \\
\hline & & Waha-2 & 24 & $0.37 \pm 0.17$ & 0.83 & 20.6 & 1.0 & & 0.9 \\
\hline 2 & & Furosia & 96 & $0.92 \pm 0.27$ & 0.87 & 21.6 & 1.4 & & 1.3 \\
\hline 3 & \multirow{2}{*}{ Middle } & Zawaida & 3 & $0.17 \pm 0.08$ & 1.05 & 20.0 & 0.9 & \multirow{2}{*}{0.9} & 1.3 \\
\hline 4 & & Deir El Balah & 5 & $0.24 \pm 0.11$ & 0.88 & 21.2 & 0.9 & & 0.8 \\
\hline 5 & \multirow{2}{*}{ South } & Khan Younis & 26 & $8.20 \pm 1.20$ & 0.89 & 18.5 & 5.9 & \multirow{2}{*}{5.5} & 4.6 \\
\hline 6 & & Rafah & 15 & $3.51 \pm 0.67$ & 0.93 & 19.0 & 5.1 & & 3.7 \\
\hline
\end{tabular}


Table 4. Sensitivity analysis for the effect of ${ }^{222} \mathrm{Rn}$ offshore to the calculated submarine groundwater discharge (SGD) rate.

\begin{tabular}{cccc}
\hline & \multicolumn{3}{c}{$\begin{array}{c}\text { Final SGD Rate }\left(\mathbf{c m} \cdot \mathbf{d a y}^{\mathbf{- 1}} \mathbf{)}\right. \\
\text { with }\end{array}$} \\
& $\mathbf{2 2 2} \mathbf{R n}$ Offshore $\left(\mathbf{d p m} \cdot \mathbf{m}{ }^{-3}\right)$ \\
\cline { 2 - 4 } Location Name & $\mathbf{1 0 0 0}$ & $\mathbf{2 0 0 0}$ \\
\hline Waha-1 & 2.2 & 2.0 & 1.9 \\
Waha-2 & 1.0 & 1.0 & 1.0 \\
Furosia & 1.4 & 1.4 & 1.3 \\
Zawaida & 0.8 & 0.9 & 1.0 \\
Deir El Balah & 0.8 & 0.9 & 1.1 \\
Khan Younis & 6.7 & 5.9 & 6.0 \\
Rafah & 5.1 & 5.1 & 5.1 \\
\hline
\end{tabular}
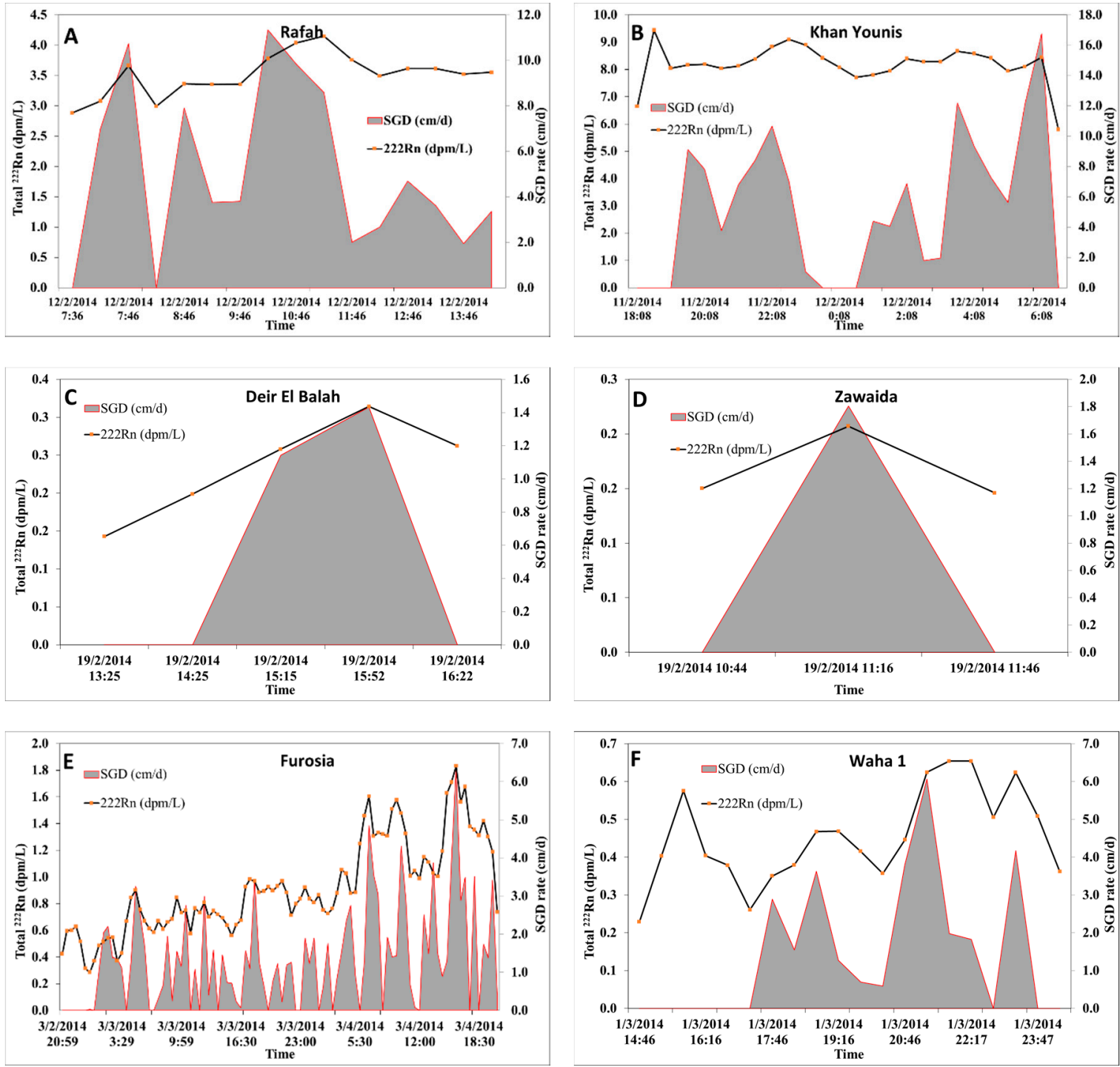

Figure 5. Cont. 


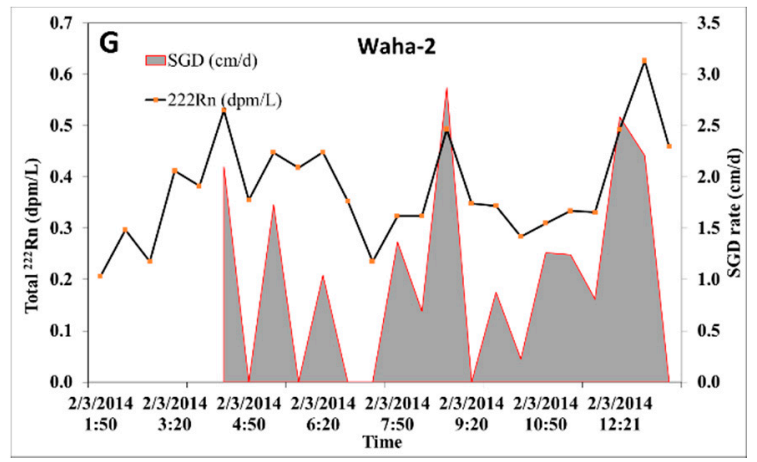

Figure 5. Radon in water and SGD rate in (A) Rafah, (B) Khan Younis, (C) Deir El Balah, (D) Zawaida, (E) Furosia, (F) Waha-1 and (G) Waha-2.

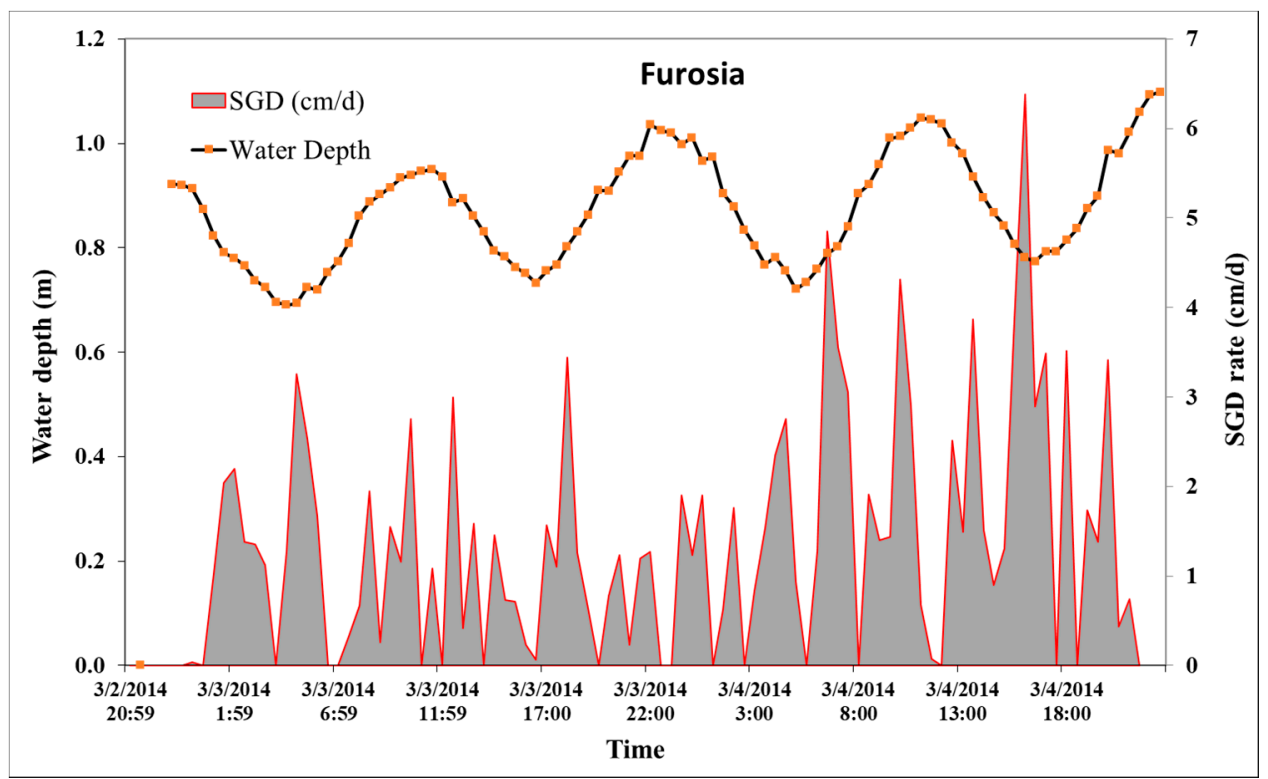

Figure 6. Relationship between ebb/flood tide and the SGD rates.

\section{Discussion}

This is the first study that has been carried out to quantify submarine groundwater discharge in the Gaza Strip, whereas seawater intrusion has been studied in this area, due to extensive abstraction and low groundwater recharge. Gaza Strip groundwater abstraction amounts to 170 million $\mathrm{m}^{3}$ [24,42], while the long term rainfall recharge is 24.4 million $\mathrm{m}^{3}$ /year [21], leading to lowering of the groundwater level by more than $10 \mathrm{~m}$ in the south, and $5 \mathrm{~m}$ in the north.

Nutrient analysis is a good way to identify potential locations of SGD occurrence, taking into consideration any other nutrient source (i.e., sewage outflow to the sea and/or agricultural activities close to the sea). Seawater is mainly poor in nutrients; hence, any high level of nutrients along the shoreline would be from groundwater. In this study, we used the nutrient analysis to indicate the potential sites for SGD, and to identify potential radon measuring sites. We found that the average $\left(\mathrm{NO}_{3}{ }^{-}+\mathrm{NO}_{2}{ }^{-}\right)$in all groups had increased values. Also, considering the high $\mathrm{NH}_{4}{ }^{+}$concentration in coastal samples compared to the seawater to be within the range of the onshore groundwater wells, this allowed us to conclude that SGD was indeed taking place.

Phosphate is as low as $5 \mu \mathrm{M}$ in the groundwater wells, probably due to phosphate removal by water-rock interaction, while the coastal samples showed higher phosphate concentration in all groups, except the samples in Rafah governorate. 
Only one method of SGD quantification has been applied in the study area, while other tools could not be carried out to enhance the accuracy of the outcomes. Seepage meters collecting in situ pore water in a closed system, are expected to provide more reliable results on the local scale.

The results show a variation in SGD quantity from the north to the south of Gaza Strip, where the southern part has higher fluxes than the north, while the middle area of Gaza Strip has a low quantity of SGD.

In the northern part of the Gaza Strip, where three continuous radon measurements were performed, the SGD rates were in the range of 1.0 to $2.0 \mathrm{~cm} \cdot$ day $^{-1}$ (average of $1.5 \mathrm{~cm} \cdot$ day $^{-1}$ ). On the other hand, the SGD rates were higher in the south (range of 5.1 to $5.9 \mathrm{~cm} \cdot \mathrm{day}^{-1}$ ), while they were minimal in the middle part $\left(0.9 \mathrm{~cm} \cdot\right.$ day $\left.^{-1}\right)$. It was calculated (Table 5) that, considering solely a strip of $1 \mathrm{~m}$ wide along the coastline, in the north, a groundwater quantity of $97 \times 10^{3} \mathrm{~m}^{3} /$ year is discharged into the Mediterranean Sea, while this is only $31 \times 10^{3} \mathrm{~m}^{3}$ /year in the middle part, and a large flux of $247 \times 10^{3} \mathrm{~m}^{3}$ /year in the south. The results thus show a variation in SGD quantity from the north to the south of the Gaza Strip, where the southern part shows higher fluxes than the north, while the middle area shows low quantities of SGD.

Table 5. SGD and associated nutrient discharge occurring in a $1 \mathrm{~m}$ wide strip along the Gaza coast.

\begin{tabular}{|c|c|c|c|c|c|c|c|}
\hline \multirow{2}{*}{$\begin{array}{c}\text { Area } \\
\text { (Group) }\end{array}$} & \multirow{2}{*}{$\begin{array}{c}\text { Coastline } \\
\text { Length }(\mathbf{k m})\end{array}$} & \multicolumn{2}{|c|}{ SGD } & \multirow[b]{2}{*}{$\mathrm{NO}_{3}{ }^{-}$} & \multirow[b]{2}{*}{$\mathrm{NO}_{2}{ }^{-}$} & \multirow[b]{2}{*}{$\mathrm{NH}_{4}{ }^{+}$} & \multirow[b]{2}{*}{$\mathrm{PO}_{4}{ }^{3-}$} \\
\hline & & $\begin{array}{l}\text { Rate } \\
\text { cm/day }\end{array}$ & $\begin{array}{l}\text { Quantity } \\
\mathrm{m}^{3} / \text { year }\end{array}$ & & & & \\
\hline \multirow{2}{*}{ North } & \multirow{2}{*}{18.1} & \multirow{2}{*}{1.5} & \multirow{2}{*}{97,116} & $316.2 \mu \mathrm{M}$ & $3.9 \mu \mathrm{M}$ & $380.8 \mu \mathrm{M}$ & $11 \mu \mathrm{M}$ \\
\hline & & & & $1412.6 \mathrm{~kg} /$ year & $23.5 \mathrm{~kg} /$ year & $665.7 \mathrm{~kg} /$ year & $101.5 \mathrm{~kg} /$ year \\
\hline \multirow{2}{*}{ Middle } & \multirow{2}{*}{9.5} & \multirow{2}{*}{0.9} & \multirow{2}{*}{31,208} & $254.7 \mu \mathrm{M}$ & $9.9 \mu \mathrm{M}$ & $373.3 \mu \mathrm{M}$ & $6.5 \mu \mathrm{M}$ \\
\hline & & & & $365.6 \mathrm{~kg} /$ year & $19.2 \mathrm{~kg} /$ year & $209.7 \mathrm{~kg} /$ year & $19.3 \mathrm{~kg} /$ year \\
\hline \multirow{2}{*}{ South } & \multirow{2}{*}{12.3} & \multirow{2}{*}{5.5} & \multirow{2}{*}{246,923} & $201.4 \mu \mathrm{M}$ & $3.2 \mu \mathrm{M}$ & $362.5 \mu \mathrm{M}$ & $5.6 \mu \mathrm{M}$ \\
\hline & & & & $2287.6 \mathrm{~kg} /$ year & $49.0 \mathrm{~kg} /$ year & $1611.2 \mathrm{~kg} /$ year & $131.4 \mathrm{~kg} /$ year \\
\hline \multicolumn{3}{|c|}{$\begin{array}{l}\text { Total for all Gaza Strip coastline } \\
\text { (1 m wide strip) }\end{array}$} & 375,246 & 4066 kg/year & $92 \mathrm{~kg} /$ year & $2487 \mathrm{~kg} /$ year & $252 \mathrm{~kg} /$ year \\
\hline
\end{tabular}

Calculating SGD quantity in a $1 \mathrm{~m}$ wide strip along the whole Gaza coastline results in total SGD of 0.38 million $\mathrm{m}^{3}$ /year, where the SGD quantity in the south is more than two times higher compared to the north. SGD may be expected to occur over a much wider area, although the rates can be expected to decrease with increasing distance from the coast. For this reason, we refrain from taking the whole outcrop area of Kurkar Group at the sea bottom into account, as the measured SGD may be expected to represent the maximum rates, which are not representative for the whole submarine outcrop area. Considering that SGD would occur with this rate in a strip of $100 \mathrm{~m}$ wide (which still appears to be a conservative estimate), results in a quantity of 38 million $\mathrm{m}^{3}$ of groundwater being discharged yearly to the Mediterranean Sea along Gaza coast.

The reason behind having higher SGD in the south compared to the north, while the recharge rate from rainfall is higher in the north than in the south [21], probably refers to the amount of abstraction quantities (in the north, $61.6 \%$ of total groundwater abstraction (for domestic water supply) is located, while it is only $16.4 \%$ in the middle area and $22 \%$ in the southern part of Gaza Strip; [24]). More abstraction in the north leads to less groundwater discharge to the sea. On the other hand, the low SGD rate in the middle part of Gaza Strip $\left(0.9 \mathrm{~cm} \cdot\right.$ day $^{-1}$ on average $)$ is probably related to the presence of Sabkhas, which act as discharge areas for groundwater and intercept the groundwater before it can reach the sea.

In a coastal strip of only $1 \mathrm{~m}$ wide, a yearly discharge of over 4 tons of nitrate and 2.5 tons of ammonium to the Mediterranean Sea occurs (Table 5). Assuming that SGD with the measured rates would occur in a strip of $100 \mathrm{~m}$ wide, would result in nutrient discharges that are one hundred times larger than calculated in Table 5, that is, over 400 tons of nitrate and 250 tons of ammonium that are yearly discharged by Gaza Strip groundwater into the sea. 
The obtained results from using different ${ }^{222} \mathrm{Rn}$ offshore values (Table 4) showed no significant difference to the overall calculated SGD rate, which gave us confidence to use ${ }^{222} \mathrm{Rn}$ offshore, as stated in Peterson et al. [40].

\section{Conclusions}

Using nutrient analytical results along the shoreline helps us to identify potential sites of submarine groundwater discharge, after eliminating sites where nutrients may be due to other potential sources (such as sewage outflow to the shoreline and/or agricultural practices that are close to the shoreline). In our study, the raised nutrient concentrations in shallow groundwater collected near the shoreline, helped us to confirm that SGD is taking place, and that it can be further investigated by the means of ${ }^{222} \mathrm{Rn}$ measurements.

Gaza Strip has suffered from seawater intrusion in the past few decades, even though groundwater discharge to the Mediterranean Sea is still occurring, with a range of up to $5.9 \mathrm{~cm} \cdot \mathrm{day}^{-1}$ (in the selected sites the minimum SGD rate was $0.9 \mathrm{~cm} \cdot$ day $^{-1}$ ). SGD rate was found to be maximal in the south of Gaza Strip (average of $5.5 \mathrm{~cm} \cdot$ day $^{-1}$ ), while being much lower in the north (average of $1.5 \mathrm{~cm} \cdot$ day $^{-1}$ ) in spite of the substantially higher groundwater recharge in the north. This must be related to groundwater exploitation, which is much higher in the north. In central Gaza, measured SGD rate is minimal (average of $0.9 \mathrm{~cm} \cdot$ day $^{-1}$ ), which must be due to the presence of Sabkhas, acting as groundwater discharge areas, and intercepting the groundwater before it reaches the sea. The sensitivity analysis carried out for ${ }^{222} \mathrm{Rn}$ offshore showed no major effect on the calculated SGD rate in our study.

The analysis showed a groundwater discharge to the sea of about 0.38 million $\mathrm{m}^{3} /$ year in a $1 \mathrm{~m}$ wide strip along the full length of Gaza coast. Assuming that the same SGD rate occurs in a $100 \mathrm{~m}$ wide strip, this results in a yearly SGD quantity of 38 million $\mathrm{m}^{3} /$ year along the Gaza coastline. This SGD transports over 400 tons of nitrate and 250 tons of ammonium to the Mediterranean Sea.

Regular measurements of SGD will enhance our understanding of water balance in the Gaza Strip, and describe the temporal and spatial variability of SGD along the Gaza coastal aquifer.

Author Contributions: Writing-review \& editing, A.M. and K.W.

Funding: This research received no external funding.

Acknowledgments: The authors thank Jehad Dasht, and Ramadan Murtaja for their assistance in the field, while continuous radon measurements were performed. We thank Fadi Abo Shanab for his assistance in analyzing the nutrient samples. We are grateful to the Global Minds Fund of Ghent University for providing some funding for a research stay for Ashraf Mushtaha in Ghent. The authors want to thank the two anonymous reviewers, whose constructive criticism contributed to substantially improving the paper.

Conflicts of Interest: The authors declare no conflicts of interest.

\section{References}

1. Zektzer, I.S.; Ivanov, V.A.; Meskheteli, A.V. The problem of direct groundwater discharge to the seas. J. Hydrol. 1973, 20, 1-36. [CrossRef]

2. Moore, W.S. The subterranean estuary: A reaction zone of ground water and sea water. Mar. Chem. 1999, 65, 111-125. [CrossRef]

3. Burnett, W.C.; Dulaiova, H. Estimating the dynamics of groundwater input into the coastal zone via continuous radon-222 measurements. J. Environ. Radioact. 2003, 69, 21-35. [CrossRef]

4. Buddemeier, R.W. Groundwater flux to the ocean: Definitions, data, applications, uncertainties. In Groundwater Discharge in the Coastal Zone: Proceedings of an International Symposium; Buddemeier, R.W., Ed.; IGBP: Texel, The Netherlands, 1996; pp. 16-21.

5. Dollar, S.J.; Atkinson, M.J. Effects of nutrient subsidies from groundwater to nearshore marine ecosystems off the island of Hawaii. Estuar. Coast. Shelf Sci. 1992, 35, 409-424. [CrossRef]

6. Paerl, H.W. Coastal eutrophication and harmful algal blooms: Importance of atmospheric deposition and groundwater as "new" nitrogen and other nutrient sources. Limnol. Oceanogr. 1997, 42, 1154-1165. [CrossRef] 
7. Miller, D.C.; Ullman, W.J. Ecological consequences of ground water discharge to Delaware Bay, United States. Groundwater 2004, 42, 959-970. [CrossRef]

8. Dailer, M.L.; Ramey, H.L.; Saephan, S.; Smith, C.M. Algal $\delta 15 \mathrm{~N}$ values detect a wastewater effluent plume in nearshore and offshore surface waters and three dimensionally model the plume across a coral reef on Maui, Hawai'i, USA. Mar. Pollut. Bull. 2012, 64, 207-213. [CrossRef]

9. Amato, D.W.; Bishop, J.M.; Glenn, C.R.; Dulai, H.; Smith, C.M. Impact of submarine groundwater discharge on marine water quality and reef biota of Maui. PLOS ONE 2016, 11, e0165825. [CrossRef]

10. Kelly, J.L.; Dulai, H.; Glenn, C.R.; Lucey, P.G. Integration of aerial infrared thermography and in situ radon-222 to investigate submarine groundwater discharge to Pearl Harbor, Hawaii, USA. Limnol. Oceanogr. 2018, 9999, 1-20. [CrossRef]

11. Weinstein, Y.; Yechieli, Y.; Shalem, Y.; Burnett, W.C.; Swarzenski, P.W.; Herut, B. What Is the Role of Fresh Groundwater and Recirculated Seawater in Conveying Nutrients to the Coastal Ocean? Environ. Sci. Technol. 2011. [CrossRef]

12. Lebbe, L.C. The subterranean flow of fresh and salt water underneath the western Belgian beach. Proceedings of the Seventh Salt Water Intrusion Meeting, Uppsala. Sver. Geol. Unders. Rap. Medd. 1981, 27, 193-219.

13. Werner, A.D.; Lockington, D.A. Tidal impacts on riparian salinities near estuaries. J. Hydrol. 2006, 328, 511-522. [CrossRef]

14. Bishop, J.M.; Glenn, C.R.; Amato, D.W.; Dulai, H. Effect of land use and groundwater flow path on submarine groundwater discharge nutrient flux. J. Hydrol. Reg. Stud. 2017, 11, 194-218. [CrossRef]

15. Burnett, W.C.; Cable, J.E.; Corbett, D.R.; Chanton, J.P. Tracing groundwater flow into surface waters using natural 222Rn. In Groundwater Discharge in the Coastal Zone: Proceedings of an International Symposium; Buddemeier, R.W., Ed.; IGBP: Texel, The Netherlands, 1996; pp. 22-28.

16. Cable, J.E.; Burnett, W.C.; Chanton, J.P.; Weatherly, G. Modeling groundwater flow into the ocean based on 222Rn. Earth Planet. Sci. Lett. 1996, 144, 591-604. [CrossRef]

17. Corbett, D.R.; Burnett, W.C.; Cable, P.H. Tracing of groundwater input into Par Pond, Savannah River Site by Rn-222. J. Hydrol. 1997, 203, 209-227. [CrossRef]

18. Burnett, W.; Chariton, J.; Christoff, J.; Kontar, E.; Krupa, S.; Lambert, M.; Moore, W.; O’Rourke, D.; Paulsen, R.; Smith, C.; et al. Assessing methodologies for measuring groundwater discharge to the ocean. EOS 2002, 83, 117, 122-123. [CrossRef]

19. Lane-Smith, D.R.; Burnett, W.C.; Dulaiova, H. Continuous radon-222 measurements in the coastal zone. Sea Technol. 2002, 43, 37-45.

20. Burnett, W.C.; Kim, G.; Lane-Smith, D. A continuous radon monitor for assessment of radon in coastal ocean waters. J. Radioanal. Nucl. Chem. 2001, 249, 167-172.

21. Mushtaha, A.; Van Camp, M.; Walraevens, K. Evolution of runoff and groundwater recharge in the Gaza Strip over the four decades. Environ. Earth Sci. 2018. under review.

22. PWA/USAID. Integrated Aquifer Management Plan; PWA: Gaza Strip, Palestine, 2000.

23. Mushtaha, A.; Aliewi, A.; Mackay, R. The Use of Scavenger Wells to Control Saltwater Upconing in Gaza, Palestine. In Proceedings of the 16th Salt Water Intrusion Meeting, Miedzyzdroje-Wolin Island, Poland, 12-15 June 2000; pp. 109-116.

24. PWA. Water Resources Status Summary Report/Gaza Strip; Water Resources Directorate: Palestinian Water Authority, Palestine, 2017.

25. PWA. Water Resources Status Report for Year 2014/Gaza Strip; Water Resources Directorate: Palestinian Water Authority, Palestine, 2015.

26. Greitzer, Y.; Dan, J. The Effect of Soil Landscape and Quaternary Geology on the Distribution of Saline and Fresh Water Aquifers in the Coastal Plain of Israel; Tahal Water Planning for Israel, Ltd.: Tel Aviv, Israel, 1967.

27. Kress, N.; Herut, B. Spatial and seasonal evolution of dissolved oxygen and nutrients in the Southern Levantine Basin (Eastern Mediterranean Sea): Chemical characterization of the water masses and inferences on the high N:P ratio. Deep Sea Res. 2001, 48, 2347-2372. [CrossRef]

28. Dulaiova, H.; Gonneea, M.E.; Henderson, P.B.; Charette, M.A. Geochemical and physical sources of radon variation in a subterranean estuary-Implications for groundwater radon activities in submarine groundwater discharge studies. Mar. Chem. 2008, 110, 120-127. [CrossRef]

29. Dulaiova, H.; Burnett, W.C. Radon loss across the water-air interface (Gulf of Thailand) estimated experimentally from ${ }^{222} \mathrm{Rn}^{224} \mathrm{Ra}$. Geophys. Res. Lett. 2006, 33. [CrossRef] 
30. Dulaiova, H.; Burnett, W.C.; Chanton, J.P.; Moore, W.S.; Bokuniewicz, H.J.; Charette, M.A.; Sholkovitz, E. Assessment of Submarine Groundwater Discharges into West Neck Bay, New York, via Natural Tracers. Cont. Shelf Res. 2006, 26, 1971-1983. [CrossRef]

31. Christoff, J.L. Quantifying Groundwater Seepage into a Shallow Near-Shore Coastal Zone by Two Techniques. Master's. Thesis, Florida State University, Tallahassee, FL, USA, 2001.

32. Dulaiova, H.; Burnett, W.C.; Wattayakorn, G.; Sojisuporn, P. Are Groundwater Inputs into River-Dominated Areas Important? The Chao Phraya River-Gulf of Thailand. Limnol. Oceanogr. 2006, 51, 2232-2247. [CrossRef]

33. Mulligan, A.E.; Charette, M.A. Intercomparison of submarine groundwater discharge estimates from a sandy unconfined aquifer. J. Hydrol. 2006, 327, 411-425. [CrossRef]

34. Chidambaram, S.; Nepoliana, M.; Ramanathan, A.L.; Sarathidasan, J.; Thilagavathi, R.; Thivya, C.; Prasanna, M.V.; Srinivasamoorthy, K.; Jacob, N.; Mohokar, H. An attempt to identify and estimate the subsurface groundwater discharge in the south east coast of India. Int. J. Sustain. Built Environ. 2017, 6, 421-433. [CrossRef]

35. Broecker, W.S. An application of natural radon to problems in oceanic circulation. In Symposium on Diffusion in the Oceans and Fresh Waters; Ichiye, D.T., Ed.; Lamont Geological Observatory: New York, NY, USA, 1965; pp. 116-145.

36. Mathieu, G.; Biscayne, P.; Lupton, R.; Hammond, D. System for measurements of 222Rn at low levels in natural waters. Health Phys. 1988, 55, 989-992. [CrossRef]

37. Ray, R.L.; Dogan, A. Contemporary Methods for Quantifying Submarine Groundwater Discharge to Coastal Areas. In Emerging Issues in Groundwater Resources. Advances in Water Security; Fares, A., Ed.; Springer: Cham, Switzerland, 2016. [CrossRef]

38. Burnett, W.C.; Santos, I.R.; Weinstein, Y.; Swarzenski, P.W.; Herut, B. Remaining uncertainties in the use of $\mathrm{Rn}-222$ as a quantitative tracer of submarine groundwater discharge. In Proceedings of the International Symposium: A New Focus on Groundwater-Seawater Interactions, Perugia, Italy, 2-13 July 2007; pp. 109-118.

39. Weinstein, Y.; Burnett, W.C.; Swarzenski, P.W.; Shalem, Y.; Yechieli, Y.; Herut, B. Role of aquifer heterogeneity in fresh groundwater discharge and seawater recycling: An example from the Carmel coast, Israel. J. Geophys. Res. 2007, 112, C12016. [CrossRef]

40. Peterson, N.R.; Burnett, W.C.; Taniguchi, M.; Chen, J.; Santos, I.R.; Ishitobi, T. Radon and radium isotope assessment of submarine groundwater discharge in the Yellow River delta, China. J. Geophys. Res. 2008, 113, C09021. [CrossRef]

41. Hampson, B.L. The Analysis of Ammonia in Polluted sea water. Water Res. 1977, 11, 305-308. [CrossRef]

42. CMWU. Water Resource Status in the Gaza Strip; Coastal Municipalities Water Utility: Al-Zahraa City, Palestine, 2013.

C 2018 by the authors. Licensee MDPI, Basel, Switzerland. This article is an open access article distributed under the terms and conditions of the Creative Commons Attribution (CC BY) license (http://creativecommons.org/licenses/by/4.0/). 